\title{
Restytucja patriarchatu na Soborze Lokalnym Rosyjskiego Kościoła Prawosławnego (1917-1918)
}

\author{
Ks. Jarosław Szczur \\ Katolicki Uniwersytet Lubelski \\ Polska \\ ojaroslawszczur@gmail.com
}

\begin{abstract}
Rev. Jarosław Szczur, Restoration of the Patriarchate at the Local Council of the Russian Orthodox Church (1917-1918), Elpis, 19
\end{abstract} 2017: 121-126.

\begin{abstract}
The beginning of the 20th century was a crucial period for the life the Orthodox Church in Russia. The main event, which changed the internal and external situation, was the Local Council of the Russian Orthodox Church in 1917/1918. The most important decision of the council was the restoration of the patriarchate, which was destroyed by a resolution of tsar Peter the First in 18th century. The discussion concerning this process initiated numerous interesting opinions and dialectic directions. In this article positive arguments for restoration of patriarchate have been presented on the basis of publications by S.N. Bułgakow, N.I. Troicki and A.W. Wasiljew, which supplemented the work of the council. Their relation to the marks of the Church such as unity, apostolicity, and conciliarity (sobornost') is of particular importance.
\end{abstract}

\begin{abstract}
Streszczenie: Początek XX wieku był okresem przełomowym dla życia Kościoła prawosławnego w Rosji. Głównym wydarzeniem, które zmieniło sytuację zewnętrzną i wewnętrzną Kościoła był Lokalny Sobór Rosyjskiego Kościoła Prawosławnego w latach 19171918. Najważniejszą decyzją soborowych obrad była restytucja patriarchatu, zlikwidowanego rezolucjami cara Piotra I w XVIII wieku. Zainicjowana dyskusja wokół tego procesu była źródłem wielu interesujących wypowiedzi i kierunków dialektyki. W niniejszym artykule prezentowana jest pozytywna argumentacja w celu restytucji patriarchatu w oparciu o publikacje S.N. Bułgakowa, N.I. Troickiego i A.W. Wasiljewa, które były dodatkiem do prac soboru. Szczególnie ważne jest ich odniesienie do przymiotów Kościoła: jedności, apostolskości i soborowości.
\end{abstract}

Keywords: Council, Patriarchate, Russian Orthodox Church

Słowa kluczowe: sobór, patriarchat, Rosyjski Kościół Prawosławny

Sobór Lokalny Rosyjskiego Kościoła Prawosławnego w latach 1917-1918 należy do panteonu najważniejszych wydarzeń XX-wiecznej historii Kościoła prawosławnego w Rosji. Przygotowania do soboru rozpoczęły się już w marcu 1906 roku, gdy car Mikołaj II zezwolił na powołanie tzw. Instytucji przedsoborowej pod przewodnictwem metropolity Petersburga ${ }^{1}$. Jednkaże w wyniku złożonej sytuacji polityczno-społeczenej w kraju, zwołanie soboru odłożono na nieokreślony czas. Kolejny etap przygotowań datowany jest na 29 kwietnia 1917 roku, gdy Święty Synod zadecydował o powołaniu Rady przedsoborowej ${ }^{2}$. Zadaniem tego organu było przygotowanie problematyki, którą miałby zająć się planowany sobór. Priorytetem stanowiącym centrum dyskusji kościelnej była restytucja patriarchatu ${ }^{3}$, zlikwidowanego reformami kościelnymi cara Piotra I w XVIII wieku. Celem artykułu jest przedstawienie ówczesnej, pozytywnej argumentacji dotyczącej tego zagadnienia, w oparciu o materiał źródłowy, jakim są

Д.В. Поспеловский, Русская православная иерков в ХХ веке, Москва 1995, s. 29.

2 С. Бычков, Большевики против Русской Церкви. Очерки по истории Русской Церкви (1917-1941 г2.), Т. 2, Москва 2006, s. 87.

3 W artykule słowo patriarchat używane jest w znaczeniu organizacji struktur kościelnych tj. synodu biskupów z patriarchą na czele, co w języku rosyjskim wyrażane jest określeniem патриаршество. referaty S. N. Bułgakowa, N. I. Troickiego i A. W. Wasiljewa, które stanowią dodatek do prac soboru (nr 31) z 28 października 1917 roku.

\section{Jedność patriarchatu}

Aktywnym uczestnikiem prac soborowych był prof. Sergiusz Nikołajewicz Bułgakow (1871-1944), późniejszy duchowny i wybitny teolog pracujący w Prawosławnym Teologicznym Instytucie Świętego Sergiusza w Paryżu. Na Soborze Lokalnym RKP ${ }^{4}$ szczególnie ważny był głos Profesora w sprawie aktywności przedstawicieli soboru w Przedparlamencie ${ }^{5}$ oraz praca nad przesłaniem do narodu w kwestii wyborów do Wszechrosyjskiego Zgromadzenia Ustawodawczego. Niemniej jednak, jako bardziej istotna jawi się jego merytoryczna argumentacja na rzecz restytucji patriarchatu w zarządzaniu Kościołem prawosławnym w Rosji.

S. Bułgakow, dążenie do wyborów patriarchy nazywa „nowymi duchowymi narodzinami”. To określenie

\footnotetext{
4 RKP - Rosyjski Kościół Prawosławny.

5 Tymczasowa rada Rosyjskiej Federacji (Przedparlament) - organ doradczy przy Rządzie Tymczasowym.

6 Документы Священного Собора Православной Российской Церкви
} 
jest maksymą, która przyświeca całości aktualnego życia Kościoła w Rosji. Według Teologa, przeprowadzenie tak istotnego działania w strukturach kościelnych, jakim jest przywrócenie urzędu patriarchy wymaga wnikliwej refleksji nad „ontologią patriarchatu”. S. Bułgakow dodaje: „Rozwiązanie kwestii patriarchatu nie może zależeć od naszych chęci lub ich braku, bowiem, oczywistym jest, że nie możemy wymyślić z własnej woli patriarchatu, jeśli nie jest on ofiarowany w tradycji i świadomości kościelnej, jak również nie możemy wstrzymać nowych narodzin, jeżeli się już dokonują" . W związku z tym restytucja patriachatu jest działaniem o wiele bardziej znaczącym, aniżeli „,archeologiczna restauracja" ${ }^{8}$ stanu sprzed reform Piotra I. Jest to „twórczy akt cerkiewnej, soborowej świadomości”". S. Bułgakow w swojej refleksji podkreśla przede wszystkim możliwość przywrócenia patriarchatu, a nie obowiązek na wzór zachodniego pojmowania prymatu pierwszego biskupa. Organizacja życia kościelnego w formie patriarchatów jest naturalnym procesem stopniowej budowy struktur administracyjnych Kościoła. W prawodawstwie religijnym po raz pierwszy tego pojęcia używa cesarz Justynian (527-565), który tworzy strukturę kościelną podzieloną na pięć patriarchatów ${ }^{10}$. S. Bułgakow wskazuje, że instutucja patriarchatu posiada swój fundament w kanonach kościelnych $^{11}$ i tradycji teologicznej, a restytucja tej struktury w Rosji jest „,wolnym ruchem miłości kościelnej”12.

Jaki status kościelny posiada patriarcha? W swych rozważaniach Teolog koncentruje się na swoistej antynomii, która w tym zakresie wyraża głębię wschodniej tradycji teologicznej. Z jednej strony, patriarcha jest tylko i wyłącznie biskupem, gdyż „wszyscy biskupi są sobie równi z punktu widzenia łaski episkopalnej, co wyklucza jakieś pojęcie nadbiskupa”"13. S. Bułgakow konstatuje: „My nie chcemy dodawać do trzech stopni kapłaństwa jeszcze czwartej, patriarcha oczywiście jest tylko biskupem"14. Z drugiej strony, kanoniczne określenie „pierwszy wśród równych" nadaje patriarsze szczególny autorytet, którego nie można opisać żadnymi formami prawnymi. Patriarcha jest biskupem, któremu powierzony został urząd zwierzchnika lokalnego Kościoła oraz przewodniczącego synodu biskupów. Jednakże autorytet patriarchy w porównaniu $\mathrm{z}$ autorytetem metropolity nie jest taki sam. W prezentacji tej antynomii, S. Bułgakow kieruje swe rozważania w kie-

\footnotetext{
1917-1918 годов, t. 5, Москва 2015, s.706.

Tamże, s. 707.

Tamże, s. 709.

Tamże, s. 707

10 W. Doroszkiewicz, Dzieje Wschodnich Rzymian, Białystok 2012, s. 68.

11 M.in. 34 Kanon Apostolski: Biskupi każdego narodu znać powinni pierwszego między sobą, za głowę go uważać i nie czynić niczego bez jego decyzji, co by ich władzę przekraczało; czynić zaś wolno każdemu jedynie, co się odnosi do jego biskupstwa i miejscowości do niego należących. Lecz i pierwszy biskup niech niczego nie czyni bez narady z wszystkimi, albowiem w ten sposób tylko może być zachowana jednomyślność i wsławiony przez Pana w Świętym Duchu Bóg, Ojciec i Syn i Święty Duch, w: A. Znosko, Kanony Kościoła Prawosławnego, Hajnówka 2000, s. 19

12 Документы, s. 708.

13 P. Evdokimow, Prawostawie, Warszawa 1986, s. 202.

14 Документы, s. 708.
}

runku chrześcijaństwa zachodniego. Stwierdza, że: „Katolicyzm w tej relacji znajduje się w o wiele bardziej wygodnej sytuacji ze swoim watykańskim dogmatem, w którym soborowość przynoszona jest $\mathrm{w}$ ofierze hierarchicznemu autorytetowi”'15. Prawosławna tradycja teologiczna w żadnym przypadku nie narusza relacji soborowości i hierarchiczności w Kościele. W konsekwencji powyższych rozważań Teolog podkreśla, że „patriarcha posiada szczególny hierarchiczny autorytet, w którym wyrażana jest żywa jedność Kościoła lokalnego"”.

Istotą pozytywnej argumentacji restytucji patriarchatu są cele, którym ma ona przyświecać. S. Bułgakow rozpoczyna swe rozważania od ukazania przyczyn erygowania patriarchatu na Rusi Moskiewskiej, które są znacząco odmienne od tych, którymi należy się kierować obecnie. Według niego: „Patriarchat odbudowuje się u nas w innych warunkach wewnętrznych i zewnętrznych, aniżeli w Rusi Moskiewskiej. Przede wszystkim, tam łączyło się to z umocnieniem władzy carskiej i służyło wywyższeniu, kosztem cierpienia i podporządkowania" ${ }^{17}$. Dodaje: „Do carskiej władzy należały legalne prawa w Kościele, z wyjątkiem tych, które uzurpowała sobie drogą cezaropapizmu"18. Warto w tym względzie nadmienić, że przy wyborze pierwszego patriarchy moskiewskiego i całej Rusi w 1589 roku, ostateczny wybór zależał od woli cara ${ }^{19}$. Znaczące dla wewnętrznej sytuacji Kościoła rosyjskiego była koncepcja Rosji jako „trzeciego Rzymu” i jej szczególnej roli na arenie międzynarodowej po upadku cesarstwa wschodniorzymskiego. S. Bułgakow swoje przemyślenia na ten temat konkluduje: „Ruś Moskiewska, szczególnie po upadku Bizancjum, była porażona chorobą religijnego nacjonalizmu, a wraz z tym i prowincjonalizmu z jego zarozumiałością. Moskwa określiła się jako „Trzeci Rzym” i swoją lokalną tradycję zaczęła bezpośrednio zrównywać $\mathrm{z}$ tradycją powszechną. Patriarchat mógł wtedy jawić się dodatkowym motywem do takiego samowywyższenia" ${ }^{20}$. Teolog krytykuje decyzje reorganizacyjne w Kościele, których dokonał car Piotr I. W głównej mierze, zamiana patriarchatu $\mathrm{w}$ urząd synodalny była umocnieniem prowincjonalizmu kościelnego nie tylko na arenie międzynarodowej, ale i w wewnętrznym życiu Rosji. Kościół prawosławny sprowadzony do roli jednej z komórek aparatu państwowego doświadczył ucisku administracyjno-prawnego oraz negacji autorytetu w świadomości społecznej. S. Bułgakow twierdzi: „Europeizując Rosję przez 'Petersburg', okno na Niemcy, Piotr zaszczepił w Rosji jad protestanckiej kultury, w tym czasie paraliżując życie Kościoła i zagradzając drogę do powszechnej samoświadomości”"21. Duchowny podkreśla, że reformy cerkiewne XVIII wieku były obopólną tragedią, państwa i Kościoła.

\footnotetext{
15 Tamże, s. 709.

16 Tamże.

17 Tamże.

18 Tamże.

19 А.П. Доброклонский, Руководство по истории Русской Церкви,

Москва 2009, s. 283.

20 Документы, s. 709

21 Tamże, s. 710.
} 
Współcześni badacze tego okresu dziejów Rosji i Kościoła prawosławnego nie są skłonni do potwierdzenia powyższych tez. Między innymi K. Chojnicka na temat roli reform konstatuje: „reformy wprowadzone przez Piotra I w efekcie doprowadziły do ustabilizowania pozycji Cerkwi w państwie, do podniesienia jej autorytetu i poziomu jej przedstawicieli, dały jej także szansę przetrwania w całości i jedności oraz uzyskania dominującej, choć nieformalnej, pozycji w świecie wschodniego chrześcijaństwa"22.

Według S. Bułgakowa, nadrzędny cel restytucji patriarchatu to odbudowanie powszechnego wymiaru Kościoła rosyjskiego, a co za tym idzie, widzialnej jedności z innymi przedstawicielami Kościołów prawosławnych na świecie. W związku z tym patriarchat będzie „organem powszechnej świadomości Kościoła prawosławnego"23. Duchowny dodaje: „Patriarcha jest kościelnym wierzchołkiem (...), widzącym inne wierzchołki i sam przez nie jest widziany"24. Argumentacja w tym zakresie, podkreśla olbrzymie znaczenie zgromadzeń (synaks) zwierzchników lokalnych Kościołów prawosławnych, którą są wyrazem jedności i powszechności Kościoła Chrystusowego. Teolog podkreśla potrzebę określenia pozycji Kościoła prawosławnego w Rosji względem innych lokalnych struktur kościelnych. Jest to potrzeba, która musi być rozpatrywana na poziomie soboru całego Kościoła. S. Bułgakow akcentuje historyczną konieczność wszechprawosławnej dyskusji na wiele tematów związanych z życiem Kościoła we współczesnym świecie. Według Teologa, problemy dotyczą spraw międzykościelnych i międzywyznaniowych, w których istotny jest dialog z Kościołem rzymskokatolickim, anglikańskim i starokatolickim.

\section{Apostolski patriarchat}

Drugim dodatkiem do prac soborowych jest tekst N. I. Troickiego (1851-1920) pt. W obronie patriarchatu. Autor publikacji był absolwentem Moskiewskiej Akademii Duchownej, wybitnym teologiem, pisarzem, archeologiem i regionalistą. Jego szczególną zasługą w pozareligijnej przestrzeni było stworzenie pierwszego muzeum tulskiej guberni oraz prezentacja dziedzictwa folklorystycznego regionu. W historii Soboru Lokalnego RKP znaczącym był jego głos na rzecz restytucji patriarchatu, w którym wybrzmiał aspekt apostolstwa patriarszego urzędu.

N. I. Troicki rozpoczyna swoje rozważania od defensywy nieścisłej koncepcji cezaropapizmu w dziejach Kościoła prawosławnego w Rosji. Historyk polemizuje z ogólną opinią powstania patriarchatu na Rusi, która koncentruje się na upadku Konstantynopola oraz rozbudowie i dążeniu do niezależności Rosji względem innych mocarstw. Taka rzeczywistość umożliwiła usamodzielnienie się Kościoła poprzez autokefalię. Według Teologa, konkluzją powyższych tez powinna być przyczynowość instytucji

\footnotetext{
22 K. Chojnicka, Cerkiew i car. Prawostawie rosyjskie $w$ reformach Piotra Wielkiego, Kraków 2011, s. 30-31.

23 Документы, s. 710.

24 Tamże.
}

patriarchatu w łonie cerkiewnym tj. w głosie hierarchii lub ludu. N. I. Troicki stwierdza, że ,inicjatywa tego dzieła powinna była pochodzić od samego Kościoła lub w szczególności od jego hierarchii: bowiem samemu Kościołowi potrzebna była ta widzialna głowa - patriarcha - dla jedności siły i upiększenia Kościoła"25. Jednakże źródłem impulsu budowy patriarszego soboru w Rosji jest osoba cara, w czym wielu upatruje ideę cazaropapizmu w jego przedsynodalnej postaci. N. I. Troicki nie podziela tego faktu i stwierdza: „Historia Dawnej Rusi zna oddzielne fakty nacisku państwowej władzy nad cerkiewną, ale, aby władza państwowa z zasady walczyła z władzą cerkiewną, w celu jej podporządkowania, to takiej pryncypialnej ambicji państwowej władzy w kierunku cerkiewnej nigdy nie było. Tym bardziej na odwrót: nikt inny, tylko $<<$ car całej Rusi >> pierwszy wzbudził dzieło budowy patriarchatu (... ${ }^{26}$. W swej argumentacji dotyczącej tego faktu, N. I. Troicki powołuje się na dzieje związane z osobami cara Fiodora, Borysa Godunowa oraz pierwszego patriarchy Hioba.

Największe znaczenie dla Teologa ma fakt inicjacji czystego cezaropapizmu za sprawą reform cerkiewnych cara Piotra I. Teolog podkreśla: „Duchowna hierarchia stała się paralelną do hierarchii państwowej i nawet do niej podobną. Hierarchowie przemienili się w dygnitarzy - według stopni..." ${ }^{27}$. Ks. G. Szawelskij tak oto prezentuje piotrowy cezaropapizm: „Będący oddzielną instytucją, Kościół prawosławny od czasów Piotra I jest w słynnej relacji częścią państwowego aparatu, jednym z państwowych instytucji, które otrzymując od państwa materialną pomoc, zobowiązuje się wypełniać państwową służbę. A przedstawiciele Kościoła w licznych odniesieniach jawią się jako agenci państwowej władzy, często zobowiązani do pełnienia państwowych funkcji ${ }^{28}$. Opisane powyżej relacje miały bezpośrednie przełożenie nie tylko na administrację Kościoła prawosławnego, ale i na obraz życia hierarchii. N. I. Troicki koncentruje się na upadku moralnym duchowieństwa w okresie synodalnym. Wyrażone jest ono w dążeniu hierarchii do zdobywania tytułów i orderów państwowych, które były podstępnym sposobem na utrzymanie posłuszeństwa i uniżenia hierarchii cerkiewnej względem organów państwowych. Teolog postuluje: „Właśnie owa, skrajna przewaga absolutnej władzy imperatora nad cerkiewną, już dawno, zrodziła konieczną potrzebę w restytucji władzy cerkiewnej, niezależnej sfery od ingerencji państwa, tj. potrzebę restytucji patriarchatu" ${ }^{29}$. Główną przyczyną historycznego kroku w kierunku przywrócenia patriarchatu jest wyrwanie administracji cerkiewnej z objęć organów państwowych.

N.I. Troicki, w kontekście całej problematyki restytucji patriarchatu, zwraca uwagę na odniesienia pomiędzy patriarchą a episkopatem RKP. W związku z tym,

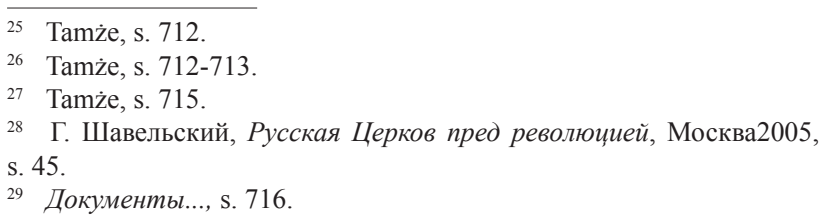


w wyjaśnieniu sformułowania „pierwszy wśród równych” uwypukla jego apostolski fundament: „Tutaj, w obszernych przemówieniach, niektórzy rozmówcy poruszali temat świętości Kościoła; liczni, aż w nadmiarze mówili o soborowości, jednakże porównywalnie bardzo mało było powiedziane o jego apostolskości” ${ }^{30}$. Filar apostolskości Kościoła, na którym Autor opiera argumentację na rzecz restytucji patriarchatu jest szczególnie istotny, albowiem określa istotę samego Kościoła. Jak podkreśla P. Evdokimow: „prawdziwe znaczenie 'apostolskości' oznacza tożsamość z istotą zarodka ponadhistorycznego powierzonego apostołom. Zasada, która pozwala stwierdzić, że Kościół w Wieczerniku w dniu Pięćdziesiątnicy, jak i w każdym momencie historii, i również dzisiaj jest zgodny z sobą samym (...)"31. Położenie akcentu na tym określeniu natury Kościoła ma za zadanie sprecyzować źródło niezbędne do ukazania relacyjnej struktury w restytuowanym patriarchacie. Nie bez znaczenia jest również przytaczany obraz pierwotnego Kościoła wraz z kolegium apostolskim, który ma wzmocnić argumentację na rzecz przywrócenia patriarchatu.

N.I. Troicki skupia się na realizacji określenia „pierwszy wśród równych" w kolegium dwunastu apostołów. Pierwszą ewangeliczną kartą, którą posługuje się Teolog jest dialog Jezusa Chrystusa z uczniami w Cezarei Filipowej. W dialogu tym najistotniejsze jest pytanie Zbawiciela o to, Kim jest dla ludzi i dla uczniów: „Gdy Jezus przyszedł w okolice Cezarei Filipowej, zapytał swoich uczniów: „Co mówią ludzie? Kim według nich jest Syn Człowieczy?”. A oni odpowiedzieli: „Mówią, że jest Janem Chrzcicielem, inni - że Eliaszem, a jeszcze inni - że Jeremiaszem lub którymś z proroków”. Zapytał ich: „A według was Kim jestem?”. Wtedy Szymon Piotr odpowiedział: „Ty jesteś Chrystusem, Synem Boga żywego"(Mt 16, 13-16). Teolog podsumowuje: „W momencie swojego wystąpienia apostoł Szymon był całkowicie równy z innymi: $\mathrm{w}$ tym momencie nie posiadał jeszcze tego znamiennego określenia Kefas lub Piotr, które dane mu było po jego odpowiedzi - wyznaniu”32. Dodaje również, że „określenie Kefas lub Piotr, co oznacza „skała” jest wyróżnieniem czci, a nie przywilejem władzy" ${ }^{\prime 3}$. Dla potwierdzenia, Autor przywołuje również wydarzenia związane $\mathrm{z}$ apostołami Jakubem i Janem oraz ich postawą w odniesieniu do niechętnej wobec nauczania Chrystusa samarytańskiej wioski (Mk 3, 17; Łk 9, 51-55). W tych perykopach ewangelicznych został wyeksponowany autorytet apostoła Piotra według czci, a nie specjalnych, instytucjonalnych prerogatyw.

Szczególnie ważne z perspektywy apostolskiego wymiaru patriarchatu są wydarzenia z pierwszych rozdziałów Dziejów Apostolskich. N.I. Troicki zwraca uwagę na moment wyboru do apostolskiej służby Macieja (Dz 1, 1526) oraz na wystąpienie apostoła Piotra w dniu Pięćdziesiątnicy (Dz 2, 14-36). W kontekście prezentacji relacji patriarchy i episkopatu cenne są sformułowania: „Wtedy

\footnotetext{
30 Tamże.

31 P. Evdokimow, Prawosławie, s. 206.

32 Документы, s. 717.

Tamże.
}

Piotr stanął wśród braci” i „Wtedy wystąpił Piotr w otoczeniu jedenastu". W tych wydarzeniach realizuje się idea „pierwszego wśród równych”. Apostoł Piotr występuje na równi z innymi apostołami i jego usta wyrażają to, co mówią serca wszystkich. Jak zaznacza N. I. Troicki, apostoł Piotr ,nie pragnie działać jedynowładczo, a działa w zgodności z całym Kościołem" "34. Cenna jest hermeneutyka tzw. soboru jerozolimskiego, podczas którego apostoł Piotr występuje w roli pierwszego oratora odnośnie do przyjmowania pogan do Kościoła. Jak i we wcześniejszych przypadkach słowa apostoła są wyrazem jednomyślności całej kościelnej wspólnoty - ,jednomyślnie postanowiliśmy" (Dz 15, 25). Według N.I. Trockiego apostoł Piotr jako pierwszy i równy innym jest ,prototypem wszystkich patriarchów w przyszłych wiekach Prawosławnego Kościoła Powszechnego"35. W argumentacji N.I. Troickiego istotne jest zatem umiejscowienie patriarchatu w łączności z wczesnochrześcijańską tradycją apostolską.

\section{Soborowość patriarchatu}

Patriarchat $i$ soborowość to tytuł odczytu, którego Autorem był neosłowianofil Afanasij Wasiliewicz Wasiljew (1851-1929). Ten cerkiewny działacz i publicysta uczestniczył w Lokalnym Soborze RKP jako delegat diecezji Petersburga. W swojej działalności wierny był ideom słowianofilstwa A.S. Chomiakowa i I.S. Aksakowa. Podczas obrad soboru wygłosił oficjalne pozdrowienie do członków soboru od stowarzyszenia „Soborowa Rosja”,36, którego był założycielem i przewodniczącym. Organizacja od 1905 roku popularyzowała ideę soborowości w zarządzaniu Kościołem prawosławnym w Rosji.

Artykuł A. W. Waslijewa składa się z dwóch części. W pierwszej Autor przedstawia dogmatyczno-historyczno-kanoniczną perspektywę soborowości, zaś w drugiej definiuje różnice wynikające z zarządzania Kościołem w soborowy i kolegialny sposób. W argumentacji dogmatycznej Teolog rozpoczyna swe rozważania od dogmatu trynitarnego, który jest filarem pojęcia soborowości. A. W. Wasiliej stwierdza: „Praobraz soborowości - Trójjedyny Bóg; przy równej chwale Boskich Osób w Nim jest i święty porządek. Od Jednego Źródła i Początku - Ojca - rodzi się Słowo-Syn i pochodzi Duch Święty"37. Ten wspaniały związek pomiędzy pojmowaniem życia Trójcy Świętej, a organizacją życia cerkiewnego to temat, który poruszany jest przez wielu współczesnych teologów. Między innymi Włodzimierz Łosski w swych eklezjologicznych rozważaniach podkreśla, że „zbadanie ścisłej więzi łączącej dogmat trynitarny ze strukturą administracyjną Kościoła prawosławnego mogłoby z pewnością być bardzo interesujące" ${ }^{\prime 38}$. Ojcowie Kościoła zgodnie określają trynitarną

\footnotetext{
34 Tamże, s. 718.

35 Tamże, s. 719

36 Por. Документы, s. 55.

37 Tamże, s. 719

38 Wł. Łosski, Teologia mistyczna kościoła wschodniego, Kraków 2007, s. 168 .
} 
naturę Kościoła, w której porządek kościelny ma swój praobraz w porządku Osób. Łosski wzmacnia powyższą tezę pisząc, że „dopiero w świetle dogmatu o Trójcy Świętej najcudowniejszy z atrybutów Kościoła, jakim jest jego katolickość - objawia się w swym prawdziwym, właściwie chrześcijańskim znaczeniu (...)"39. W definiowaniu pojęcia soborowość A. W. Wasiljew koncentruje się również na antropologicznych jego implikacjach. W stworzeniu człowie$\mathrm{ka}$, a konkretnie w jego naturze objawia się Bogiem ustanowiona hierarchiczność - ducha, duszy i ciała. Aspekt ten szczególnie dobitnie wyrażają dzieła Ojców Kościoła z zakresu duchowości, walki z pożądliwościami (gr. pathi) i praktyki pielęgnowania cnót. Dla A.W. Wasiljewa szczególnie ważne jest podkreślenie wyboru władzy cerkiewnej, która odbywa się w specyficzny sposób. „Nasza cerkiewna i święta władza otrzymuje swoje uświęcenie i pełną łaski siłę i władzę nie od wyboru oddolnego, a odgórnego"40. Ten Boski wybór, który odbywa się w Kościele poświadczają ewangeliczne słowa Zbawiciela - „Nie wyście mnie wybrali, ale Ja was wybrałem" (J 15, 16).

Dla Autora, niezwykle ważne jest połączenie świadomości kanonicznej Kościoła z życiem eklezjalnym. Historia kościelna jest realizacją wielopłaszczyznowości kanonów $\mathrm{w}$ jednym tenadrycznym organizmie jakim jest Kościół Boży. Teolog konkluduje: „Od dawien dawna ustanowiony, umocniony kanonami porządek zarządzania chrześcijańskimi autokefalicznymi Kościołami, przestrzegany jest na całym prawosławnym Wschodzie i do dzisiaj: każdy samodzielny Kościół prawosławny posiada swojego zwierzchnika, którego pozostali biskupi kościelnego obszaru uznają ,jako głowę”, zaś między tymi głowami autokefalicznych Kościołów pierwszeństwo czci przynależne było rzymskiemu biskupowi, a po popadnięciu tego ostatniego w herezję to pierwszeństwo przynależy patriarsze Konstantynopola [...]"41. Argumentacja Teologa skupia się również na historii patriarchatu w Rosji. Według A.W. Wasiljewa okres synodalnego zarządzania Kościołem hamował dynamikę jego rozwoju. „Kolegialne zarządzanie i porządek wyższej kościelnej władzy nie dawał tym mocarzom ducha [duchowieństwu - JS) rozwinąć w całej szerokości ich darów i przynieść ich na pożytek Kościoła w Rosji" ${ }^{42}$.

W pojęcie soborowości nieodłącznie wpisane jest posłuszeństwo. Na poziomie ontologicznym wszyscy zebrani w soborowej naturze Kościoła są sobie równi i są potencjalnymi nosicielami duchowych darów. W obejmującą pełnię Kościoła soborowość wpisana jest współ-przenikająca się relacyjna miłość rządzących i podwładnych. Jednakże w wymiarze eklezjalnym jest to relacja oparta na miłującej służbie i wolnym posłuszeństwie. A.W. Wasiljew pisze: „Tak władza, określająca siebie jako służbę, według słów [Jezusa] Chrystusa: pierwszy wśród was niech będzie sługą wszystkich, - i podwładni, dobrowolnie posłuszni ich autorytetowi, - zgoda, jednomyślność i jedna dusza,

\footnotetext{
39 Tamże.

40 Документы, s.720.

41 Tamże, s. 722.

42 Tamże, s. 723
}

u podstaw, których leży wzajemne, wspólne zaufanie i miłość - taka jest soborowość" ${ }^{43}$. Teolog w powyższej wypowiedzi pragnie podkreślić znaczenie synergicznej pracy dla dobra Kościoła i narodu. Szczególnie w obserwowanym kryzysie początku XX wieku, słowa te mają znaczenie szersze aniżeli tylko teologiczne. Autor jako działacz społeczny widzi możliwość odbudowy solidarności i ducha rosyjskiego narodu w jednoczącym centrum, którym jest osoba patriarchy. Podkreśla, że soborowość Kościoła była jednocześnie życiem soborowym narodu, na którym „do piotrowych czasów na Rusi budowana była nie tylko struktura kościelna, ale i obywatelskie oraz państwowe życie" ${ }^{44}$.

Według A.W. Wasiljewa, zasadniczą przestrzenią dyskusji na temat restytucji patriarchatu jest wielopoziomowe zło, które wniosła kolegialna struktura zarządzania Kościołem. Problemy z tym związane koncentrują się na odmiennych koncepcjach moralnych, polegających na redukcji pojęcia osoby czy minimalizacji odpowiedzialności za Kościół. Teolog spostrzega: „Soborowość jest początkiem moralnym, duchowym; kolegium zbudowane na początku formalnym. W soborowości osoba ludzka i autorytet władzy znajdują swoją akceptację i umocnienie; w kolegium autorytet ulega likwidacji a osoba jest usuwana. Decyzje podejmowane są bezosobową i obojętną większością. Soborowość nawołuje do wzajemnej miłości i dobrej woli, do zgodności ze światem, do bycia jedną duszą i do jednomyślności [...]. Soborowość przywołuje do ofiary swoich prywatnych spraw, jeśli jest to potrzebne dla innych, dla ogólnego dobra i pożytku całości” ${ }^{{ }^{45}}$. W tym wymiarze szczególnie bolesna jest utrata samoświadomości eklezjalnej. Kolegialność była naturą rozdrabniającą, a nie scalającą wiernych kościoła. Niedostatek życia eklezjalnego w kolegialnej strukturze polegał na indywidualizacji, która prowadziła do nienaturalnego wyobcowania zarządzających i zarządzanych, duchowieństwa i świeckich. Utrata natury soborowości przyniosła nie spotykany dotąd podział przedstawicielstwa na Soborze Lokalnym RKP w 1917/1918 roku. Według A.W. Wasiljewa niezrozumiałe są spory na temat głosów decydujących i doradczych w soborowych pracach. W swych wypowiedziach jest zgodny ze stanowiskiem M. Afanasjewa, który twierdzi, że takie działanie jest rozdwojeniem ciała Chrystusowego i nie występuje w tradycji cerkiewnej ${ }^{46}$. W pełni synergiczną naturę jednostki i wspólnoty uwydatniają słowa S. Bułgakowa, który pisze: „Uświadomienie sobie doświadczenia Kościoła w soborowości jest zawsze dziełem jednostki: jest to stanie duszy przed Bogiem - Bóg i moje ja w żywym i nieustannym kontakcie. Ale nie można zatrzymać się jedynie na świadomości jednostkowej, gdyż dąży ona do stania się powszechną, przechodząc swoją drogę poprzez społeczność do nowej jakości pojęcia soborowość" ${ }^{\prime 47}$.

\footnotetext{
43 Tamże, s. 724.

44 Tamże.

45 Tamże, s. 725.

46 Por. R. Kozłowski, Koncepcja Kościoła w myśli teologicznej Mikołaja Afanasjewa, Warszawa 1990, s. 84.

47 S. Bułgakow, Prawsławie, Białystok 1992, s. 87.
} 
A. W. Wasiljew podkreśla dwuwymiarowość restytucji patriarchatu, która opiera się na przywróceniu urzędu patriarchy oraz na rekapitulacji instytucji soboru. Według Teologa prócz dogmatyczno-kanonicznej podstawy „pierwszego wśród równych” znacząca jest realna potrzeba „środka jednoczącego” Kościół i naród rosyjski. Tym kim powinien być pasterz dla owczarni najpełniej wyrażają słowa modlitwy chirotonii biskupiej: „Uczyń go przewodnikiem ślepych, światłem dla pogrążonych w ciemności, nauczycielem nierozsądnych, pochodnią płonącą dla świata”48. A. W. Wasiljew podkreśla: „W obecnym czasie przy zagrażającym nam rozpadzie naszej Ojczyzny, przy oddzieleniu od niej - czego nie daj Bóg, lecz co może być dane według naszych grzechów - całych części [terytorium - JS], koniecznym jest posiadanie wiążącego centrum, żywej osoby - według słów arcybiskupa Antoniego, kochającego serca, które cierpiałoby za całą ziemię rosyjską i za całe prawosławne chrześcijaństwo" ${ }^{\text {99 }}$. Z kolei sobór, którego pozbawiony był Kościół prawosławny w Rosji, stałby się środkiem odnawiającym tradycję cerkiewną, wyrazicielem pełni natury cerkiewnej, a przede wszystkim nowym impulsem rozwoju duchowego hierarchii i wiernych. Sobór jest widzialną realizacją soborowości Kościoła. Sobory są „Bogiem natchnionymi świadkami, wyznawcami i obrońcami Bogoczłowieczej wiary"50. Dla A.W. Wasiljewa relacja patriarchy i soboru jest synergiczna, albowiem są to elementy wzajemnie się dopełniające i nierozłączne.

Cyt. za K. Ware, Kościół prawosławny, Białystok 2011, s. 276.

49 Документы, s.729.

50 Преподобный Иустин (Попович), Догматика Православной Церкви. Екклесиология, Москва 2005, s. 232.
Specyfika dyskusji soborowej wokół restytucji patriarchatu była wielopłaszczyznowa. W dużej mierze zwracano uwagę na aspekty: historyczny, dogmatyczny i kanoniczny ontologii patriarchatu oraz na aktualną sytuację Kościoła rosyjskiego u progu przemian polityczno-społecznych. Jak podkreśla K. Pawełczyk-Dura, różnorodność argumentów prezentowanych na soborze skutkuje tym, że nie można znaleźć między nimi „modus vivendi" ${ }^{51}$. W niniejszym artykule skupiono się jedynie na przedstawieniu części argumentacji, a mianowicie na ukazaniu teologicznej korelacji patriarchatu i doktrynalnych przymiotów Kościoła (jedności, soborowości, apostolskości). Merytoryczna zawartość publikacji S.N. Bułgakowa, N.I. Troickiego i A.W. Wasiljewa świadczy o problemach eklezjologicznych, które były przedmiotem ogólnocerkiewnej debaty a zarazem odpowiedzialnej postawy wobec dążenia do restytucji patriarchatu. U autorów wyczuwalna jest nie tylko przemyślana koncepcja umiejscowienia patriarchatu w nauczaniu Kościoła, ale i autentyczna troska o dobro całego organizmu kościelnego. To połączenie gruntownej wiedzy z praktycznymi potrzebami życia eklezjalnego może być inspirujące dla współczesnej dyskusji wokół zagadnień związanych ze strukturą i zarządzaniem wspólnot kościelnych.

${ }_{51}$ K. Pawełczyk-Dura, Rosyjskie prawosławie w okresie wczesnosowieckim, Lublin 2014, s. 96.

\section{Bibliografia}

Bułgakow S., Prawsławie, Białystok 1992.

Бычков С., Большевики против Русской Церкви. Очерки по истории Русской Церкви (1917-1941 г2.), Т. 2, Москва 2006.

Chojnicka K., Cerkiew i car. Prawostawie rosyjskie w reformach Piotra Wielkiego, Kraków 2011.

Доброклонский А. П., Руководство по истории Русской Церкви, Москва 2009.

Документы Священного Собора Православной Российской Церкви 1917-1918 годов, Т. 5, Москва 2015.

Doroszkiewicz W., Dzieje Wschodnich Rzymian, Białystok 2012.

Evdokimow P., Prawostawie, Warszawa 1986.
Kozłowski R., Koncepcja Kościoła w myśli teologicznej Mikołaja Afansjewa, Warszawa 1990.

Łosski Wł., Teologia mistyczna kościoła wschodniego, Kraków 2007.

Pawełczyk-Dura K., Rosyjskie prawosławie w okresie wczesnosowieckim, Lublin 2014.

Поспеловский Д. В., Русская православная церков в ХХ веке, Москва 1995.

Преподобный Иустин (Попович), Догматика Православной Церкви. Екклесиология, Москва 2005.

Ware K., Kościół prawosławny, Białystok 2011.

Znosko A., Kanony Kościoła Prawosławnego, Hajnówka 2000.

Шавельский Г., Русская Церков пред революичией, Москва 2005. 
ISSN 1508-7719

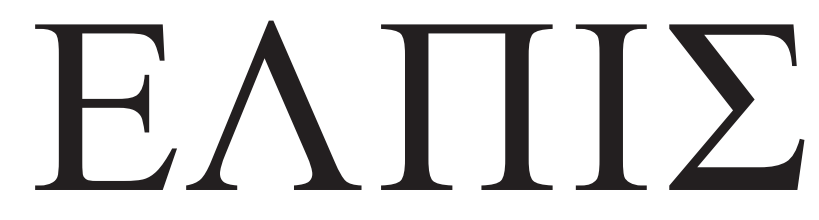

CZASOPISMO TEOLOGICZNE KATEDRY TEOLOGII PRAWOSŁAWNEJ UNIWERSYTETU W BIAŁYMSTOKU

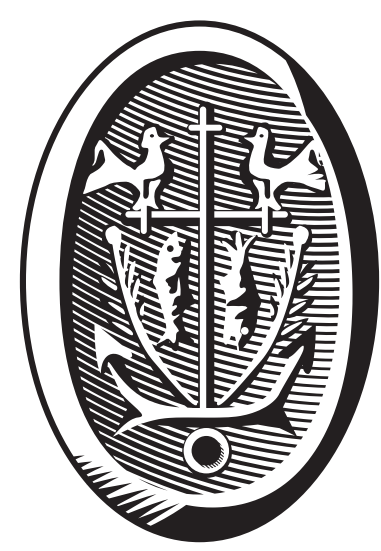

ADRES REDAKCJI

15-097 Białystok, ul. M. Skłodowskiej-Curie 14 tel. 85 745-77-80, e-mail: redakcja@elpis.edu.pl www.elpis.uwb.edu.pl 